\title{
Entrepreneurial educators: vital enablers to support the education sector to reimagine and respond to the challenges of COVID-19
}

\section{Carol Langston ${ }^{1}$ (1)}

Received: 5 September 2020 / Revised: 5 September 2020 / Accepted: 13 September 2020 /

Published online: 28 September 2020

(c) Springer Nature Singapore Pte Ltd. 2020

\begin{abstract}
This article examines the experiences of the educator as a key actor in entrepreneurship education. Since the 1990s, the education sector has been called upon to create more 'entrepreneurs' to find solutions to global problems leading to entrepreneurship education. The educator is a key participant in the process of entrepreneurship education, but too little is known or understood about their experiences. Employing an interpretative phenomenological approach with ten UK-based higher education entrepreneurship education educators, this article sheds light on their experiences. The article concludes by proposing a conceptual model of the essence of entrepreneurship education educators' experiences which identifies shared values, multiple identities and innovative practices. It finds something personal and inherently 'good' about entrepreneurship education, beyond the knowledge of entrepreneurship, which attracts certain educators. These educators are found to be entrepreneurial with a need for change, distinctiveness and action which at times can lead to marginalisation from the traditional educational establishment. They are found to be highly efficacious entrepreneurial employees (Lackéus et al., Bacigalupo (ed) The entrepreneurial employee in the public and private sector-what, why, how. Publications Office of the European Union, Luxembourg, 2020) and, it is argued, could act as significant enablers for wider educational systems change required to respond to the challenges of COVID-19 (WHO in Coronavirus disease (COVID-19) pandemic, 2020. https://www.who.int/emergencies/diseases/novel-coronavirus-2019).
\end{abstract}

Keywords Entrepreneurship $\cdot$ Education $\cdot$ Educator $\cdot$ Experience $\cdot$ Student $\cdot$ Value

Carol Langston

carol.langston@gtcs.org.uk

1 General Teaching Council for Scotland, Edinburgh, UK 


\section{Introduction}

The globally influential Handbook of Entrepreneurship Research describes an 'upending' in the understanding of entrepreneurship in the twenty-first century with entrepreneurship now being widely recognised as the driver of global economic and social development (Acs and Audretsch 2001, 2010, p. 1). For more than 20 years, the education sector has been called upon to embed entrepreneurship education. Initially with the aim to encourage new ventures by creating more 'entrepreneurs' and latterly, there has been a move towards enterprise education, particularly in Europe, to develop graduates' broader enterprising competencies in order that they are better able to find innovative solutions to societal problems and jobs in the dynamic world of work.

Particularly over the last decade, policy makers (EC 2006, 2007, 2008, 2009, 2011a, b, 2013, 2014a, b, 2015a, b, 2016, 2020), academic institutions (QAA 2012, 2014, 2018; Kauffman 2015) and economic stakeholders (WEF 2011, BIS 2014, World Bank 2014) agree that creating more graduates able to think and act entrepreneurially is a worthwhile ambition. The enduring attraction of entrepreneurship to society being 'the entrepreneur's value creation capability towards citizens of the world' Lackéus (2019, p. 282). Lackéus noted that 'making sure that educational institutions inculcate those competencies that society needs is arguably as much of an educational policy issue as an economic policy issue' $(2019$, p. 282).

The impact of the global financial crisis (2007-2008) caused many in academia to (re)consider their role in entrepreneurship. Rae (2010) was clear that the choices educators make when explaining enterprise have consequences which can perpetuate a simplified 'old view' of entrepreneurship which is often characterised by individualism, exploitation and aggressive attributes fuelled by debt (Rae 2010, p. 599). Rae (2010) recommended a more balanced, socially responsible and critical academic stance for entrepreneurship education, which has the potential to create social good with educators having a major but not exclusive role in this process. Lackéus (2019) argued that adding societal purposes can help to stop a 'definitional dilution' of enterprise education.

Entrepreneurship education as a discipline is still considered to be at an early stage of development, regarded by some as confusing or marginal, with work needed to make it more effective and available (Lackéus 2015) though expectations of what entrepreneurship education can achieve 'may have spiralled beyond what is both realistic and possible' (Henry 2013, p. 836).

The impact of the COVID-19 crisis (World Health Organisation 2020) is causing a reimagining of education with calls for radical reviews of access, curriculum and learning and teaching approaches (Peters et al. 2020; RSE 2020). Entrepreneurship is considered a vital part of the recovery of the global economy from the impact of COVID-19 (Bhatia and Levina 2020), and entrepreneurship educators are facing increasing expectations to swiftly adapt their programmes and approaches to support enhanced entrepreneurship skills development often through, for example, the incorporation of enhanced technology usage to create experiential entrepreneurial learning environments that support social distancing requirements (Ratten 2020). 
The educator is a key actor in this dynamic, but research so far has largely neglected the experiences of educators working in this field and this research study aims to address this gap.

\section{Definitions}

Understanding the concepts relating to enterprise and entrepreneurship is necessary to research practice within entrepreneurship education. Varied definitions have been proposed with different perspectives with no consensus yet reached (Lepistö and Ronkko 2013). Entrepreneurship education research is considered highly fragmented (Fayolle 2013), and entrepreneurship education is 'still claiming its autonomy' (Jones et al. 2014, p. 765). This research focuses on the experience of educators working in this arguably unclear environment.

Two of the most frequently used terms in this area are enterprise education and entrepreneurship education. The Quality Assurance Agency for Higher Education (QAA 2018) defines enterprise education as 'the generation and application of ideas, which are set within practical situations during a project or undertaking. This is a generic concept that can be applied across all areas of education and professional life. It combines creativity, originality, initiative, idea generation, design thinking, adaptability and reflexivity with problem identification, problem solving, innovation, expression, communication and practical action' $(2018$, p.7) and entrepreneurship education as a process of 'application of enterprise behaviours, attributes and competencies into the creation of cultural, social or economic value' (QAA 2018, p. 7). The definitions and mix of teaching approaches associated with each are often used interchangeably and not explicitly labelled, adding to an uncertainty and lack of accepted common purpose.

Entrepreneurship education is problematic for many teachers due to its connotations of selfishness, commercialism and capitalism. Enterprise education suffers from definitional vagueness, fuzziness and weak effects on students. The resulting situation is a dilemma where many teachers are caught between two inappropriate alternatives (Lackéus 2019, p. 273).

The focus of this research is the 'life world' (Gibb 2002) of an educator working in this arguably unclear environment, as such all experiences whether defined as entrepreneurship or enterprise education (or a derivative thereof) are considered within scope. Unless relating to a specific approach, the term entrepreneurship education (EE) will henceforth be used to cover the range of professional practice evidenced in this research. 


\section{Review of Literature}

\section{What does entrepreneurship education involve?}

EE can be broadly categorised as focusing on four main learning approaches, 'about', 'for', 'through' and 'embedded' entrepreneurship (Gibb 2009; Heinonen and Hytti 2010; Pittaway and Edwards 2012; Lackéus 2015). These four distinct teaching approaches typically considered under the umbrella term of EE comprise:

- A first approach, often referred to as a traditional 'business school' model, is to develop knowledge and understanding 'about' entrepreneurship; generally, this is in relation to the theories and concepts of business development and new venture creation (Lackéus 2015)

- A second approach surrounds the development of skills 'for' entrepreneurship such as skills to pitch for investment funds or enhance networking capacity from which to start a business or establish a social enterprise project

- A third approach is learning 'through' entrepreneurship, often using experiential education techniques such as undertaking a volunteering role or consultancy project with a small- or medium-sized business (SME), and

- A fourth approach (which can be present in each of the previous types) relates to the embedding of EE within core curriculum activity, which may not be explicitly referred to as EE for the student (Gibb 2002; Pittaway and Cope 2007). This method expects a purposeful process to inculcate entrepreneurial values and learning within generic subject learning outcomes and an adjustment to the teaching and learning strategy in order to develop the entrepreneurial competencies of students.

EE is perceived as supporting students with the knowledge to start their own business (the first typology), but also 'through' participating in EE, students are deemed to build their capacities to develop higher aspirations for their life (as described in typologies 2-4 above) (EC 2015a, p. 7). Current EE policy discourse tends to place a higher value on EE designed to offer experiences to learn 'through' entrepreneurship and encouraging EE to be 'embedded' across all academic levels of the system (EC 2006-2018; QAA 2012; BIS 2014; QAA 2018). However, Pittaway and Edwards (2012) found that:

Despite a widespread desire to promote and develop innovative forms of entrepreneurship education it is evident [from their research] that current educational practice remains fairly traditional" (Pittaway and Edwards 2012, p. 792).

By using the term 'traditional' here, Pittaway and Edwards (2012) are referring to the continued dominance of education 'about' entrepreneurship (the first typology explained above). An educator who identifies themselves as working within the field of EE may be involved in one or more of these typologies of EE.

The literature shows that these four approaches, often all defined under the umbrella definition of EE, are based on quite different conceptual understandings 
and teaching philosophies and are experienced differently by both educators and learners though there is limited research available to explain the impact of this diversity.

\section{Teaching and learning approaches}

This article doesn't aim to provide a comprehensive review of what constitutes effective teaching approaches for EE, this has been done in many contexts (see Henry and Lewis 2018), but rather to highlight key approaches specifically linked to EE which have support in the education community.

Experiential learning started to become central to progressive educational movements (such as EE) in the late twentieth century (Hagg and Kurczewska 2016). There are numerous teaching approaches which utilises experience, such as experiential learning (Dewey 1938; Garrison et al. 2012; Lewin 1946; Piaget 1972; Kolb 1984; Pittaway and Cope 2007; Hagg and Kurczewska 2016), existential learning (Jarvis 2006; Walters 2008; Robinson et al. 2016), authentic learning (Carlson 2002; Lombardi 2007; Fook and Sidhu 2010; Macht and Ball 2016) and creative/design learning (Brown 2008; Craft 2011; Penaluna and Penaluna 2009; Tanggaard 2014). These approaches are said to support the development of attributes of creativity, resilience, self-efficacy and appear well suited to the discipline of EE. These experiential methods are each also said to support the ability to cope with risk and failure (Duening 2010; Kyrö 2015) though there appears less evidence to confirm this.

Teaching and learning approaches which support the learner to develop their cognitive approaches to learning are also prominent within the EE literature. Methods found to support entrepreneurial learning include heuristics (Holcomb 2009; Powietrzynska et al. 2015); effectuation-logic (Sarasvathy and Venkataraman 2011); emotional intelligence (Welpe et al. 20121; Maguire et al. 2017); metacognition (Vanhear 2013); enhancing self-efficacy (Bandura 1977; Caird and Johnson 1988; Lucas and Cooper 2004); and social constructivism/scaffolding (Vygotsky 1929, 1978). Used effectively these methods have support amongst many in the EE academic community though some concerns are raised about how well the system supports students to cope with such personal and active methods (Kember 2009). There is general consensus in the literature regarding the need for more evidence to show which teaching approaches are most effective and of the impact of these in the context of EE (Rideout and Gray 2013).

\section{Entrepreneurial attributes and practices}

This article does not set out to provide a comprehensive review of what constitutes entrepreneurial attributes or practices as this has been done in many contexts (see Acs and Audretsch 2010). The literature was reviewed to explore attributes considered entrepreneurial which are being linked to EE and found: creativity (Ward 2004; Dunham and Venkataraman 2006; Krueger and Day 2010); resilience and self-efficacy (Bandura 1977; Lucas and Cooper 2004; Dweck 2007; Moltz 2008; Duening 2010; Prodon and Drnovsek 2010); need for achievement (McClelland 1965; Miner 
1990; Stewart and Roth 2007); effectual thinking (Sarasvathy 2001, 2009; Sarasvathy and Venkataraman 2011); and bricolage (Levi-Strauss 1967; Desa and Basu 2013; Welter et al. 2016). There was less evidence found to support a special ability to spot opportunities (Shapero 1975; Zahra et al. 2009) or cope with risk and failure (Cacciotti et al. 2016), but these attributes are found to be established within policy (QAA 2012; EC 2015a, b) and the popular media narrative and may differ in different cultural settings.

Learning gained from the review of literature helped to assess the data captured from the educators, to better understand, what entrepreneurial attributes they were trying to develop in their students, what attributes they appeared themselves to display and their EE teaching philosophy and experiences. The findings are presented in the study results.

\section{Research methodology}

Given the nature of the processes and people being studied-to understand the holistic experience of being an educator working in UK HE EE-an interpretative phenomenological approach (IPA) (Heidegger 1927; Schleiermacher 1998; Smith et al. 2009; Smith 2013) was considered most effective. The IPA methodology supported the capture of substantial rich data from each educator's perspective and how they approach and experience the emerging phenomena of EE within their context.

Sadala and Adorno (2002) recognised the developing picture of research as an advantage of a phenomenological approach which could reveal new meaning via the convergence of perspectives:

One could say that a phenomenon is never seen in its totality, because this would be an abstraction; the convergence of several perspectives, however, leads us to perceive a phenomenon's structure (Sadala and Adorno 2002, p. 287).

Criticisms of the IPA method are that it can lead to so much collected data and it can be difficult to effectively analyse to identify insights and emerging themes. To balance these concerns, a sample size of 10 educators was considered appropriate: 2 educators as pilot participants [identified as PP1 and PP2] (both met the approved research criteria) and a further 8 educators were included from across the UK [identified as P1-P8].

With such a small sample, random sampling wasn't considered valid, but rather to look purposively within the research study characteristics to define a group for whom the research area will be of significance (Chapman and Smith 2002). Patton suggests 'the overall aim of purposive, as opposed to probability, sampling is to include information-rich cases for in-depth study' (1990, p. 182) as cited in Green and Thorogood (2014, p. 122). In this study the sample criteria included employed in HE curriculum delivery involving EE; taught for at least 5 years; mixture of business school and non-business school participants; mix of job roles; gender mix ( $40 \%$ men to $60 \%$ women (considered a comparable spread with available data of participants in UK EE)); representative UK geographical 
profile; mix of university research focussed profiles; and that the employing university was a member of a UK-based entrepreneurship-related support organisation (anticipated relevance).

From the outset, throughout the interviewing process the approach was phenomenological, creating an atmosphere of open dialogue which was unrestricted and reactive rather than following a list of set questions with the interviewee able to direct the conversation. This resulted in significant, diverse and rich personal data being captured for all 10 participants (Langston 2018).

As the pursuit of 'Theory' isn't the prime objective of an IPA study the researcher was careful to avoid any tendency towards 'narrative smoothing' (Clandinin and Connelly 2000), which may potentially take place in order to 'fit' varied qualitative data to a particular theory or construct. The researcher found that the varied practices of educators working in EE captured through the interviews painted a picture of diversity which was important to capture.

The collected data were transcribed in full and uploaded into the NVivo qualitative data analysis software. The data were interrogated, actively read and reread many times (Moustakas 1994; Smith et al. 2009) to find emerging themes as 'essences' of the experiences shared. The researcher approached this with an open mind, not looking for lists of expected topics but rather searching for the essence of the experiences. This process led to unexpected new themes then being researched in the literature to better understand the concepts and themes emerging.

Finlay (2012) says that 'phenomenological writing needs to describe, and describe well' (2012, p. 190). Many writers argue this requires use of quotations to exemplify particular points to bring the phenomenon to life for the reader (Finlay 2012, p. 191; Smith et al. 2009). Brief extracts of the voice of each educator have been included within the results section below to help evoke the life world of educators working in EE for the reader (Finlay 2012).

\section{Study results}

The study results are based on a series of in-depth IPA interviews with 10 educators working in UK Higher Education Institutions (HEIs) in the field of EE. Despite being in different regions of the UK, different HEIs, in different roles and subject faculties the similarity of experiences, beliefs and philosophical choices being made by this small group of 10 educators within the emerging phenomenon of EE was found to be considerable. Particularly with respect to what they appear to think and care most about (values), how they see themselves (identities) and in what they do (learning and teaching practices).

The convergence of these complex themes has informed the development of a proposed simplified conceptual model to represent these essences as a starting point for further exploration. The model brings together the values (centre circle), identities (middle circle) and practices (outer circle). A summary of the study results (including illustrative extracts of educator voices) is set out below within the framework categories of values, identities and practices. 


\section{Values}

Throughout the interviews, the educators discussed what they value and consider important regarding their experiences as educators working in EE (Fig. 1). An educator's personal values and beliefs can influence how they personally behave and how they design learning opportunities (Palmer 1997).

\section{Reimagined futures}

The study found all the educators profess a high level of personal engagement in the values of socially responsible entrepreneurship and of its future potential benefits for their students and global communities. The analysis suggests there is

\section{Conceptual Model: The Essence Of Being an Entrepreneurial Educator}

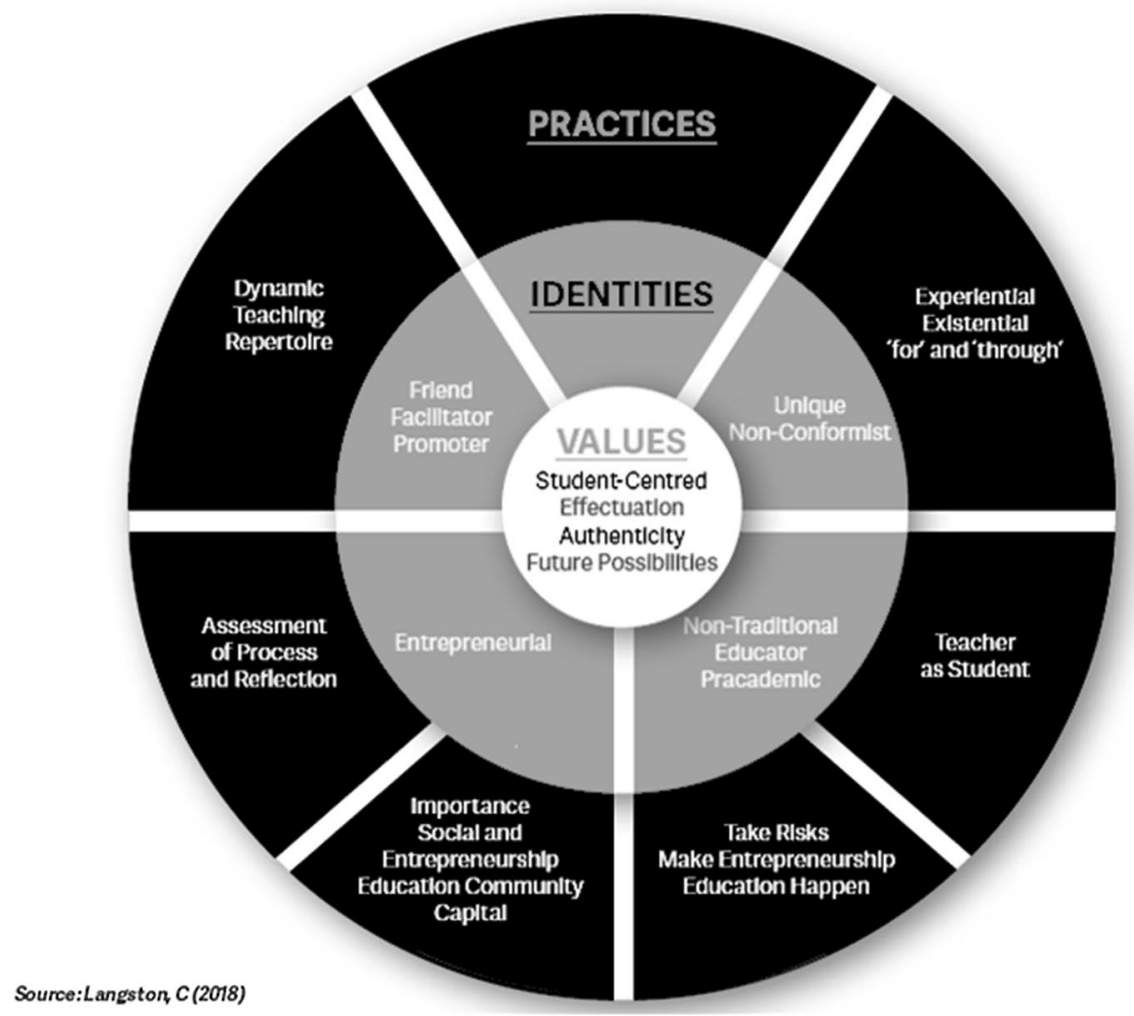

Fig. 1 Proposed conceptual model: 'the essence of being an entrepreneurial educator' 
something more personal and multi-faceted about working in the field of EE than can be explained solely by business and entrepreneurship influences. It is argued there may be something distinctive about the educators which attracts them to the area of enterprise and entrepreneurship, to believe so passionately in it.

P3 I feel that as educators we have a responsibility to educate students that entrepreneurship is not solely about venture creation and capitalist gain. That entrepreneurial skills can be and should be used to the benefit of society.

All the educators appear to consider their role involves helping to identify and foster future-possibilities and opportunities for their students, colleagues, industries and wider society often through addressing real-world problems.

P6 It opens up scope to the possibilities of them engaging in new venturing but also being much more meaningful in terms of their contribution to the development of existing enterprises, whether they're commercially or socially driven. It widens the prospects of people's thinking, considering other people's thinking socially and culturally. I actually think it's a revolution potentially.

It is also worthy of note that there were similar considerations some 10-15 years ago in early research relating to the discipline of environmental and sustainability education which posited that there appeared to be particular attributes of educators which tied them to the natural world and that these influences were deemed more complex than purely academic or interpersonal influences (Hart 2008, p. 208; Hwang 2008).

These considerations resonate closely to the discipline of EE, where the educators consistently demonstrate a passion or commitment to the discipline which seems more personal than of pure academic interest. Some educators recognise that in a research focussed university this focus may offer less career advancement than a more typical research focus.

P5 I know that my focus on my students is costly career wise cos while you're teaching, you're not researching.

Four of the 10 participants explicitly identify that their work, how it is supported and sometimes funded, is directly linked to whether senior management at the HEI sees EE as a priority, and this can shift in relation to available funding. From the terms used in the following extracts, the vexations are apparent: 'frustrations' [P1] linked to whether EE is 'popular other times unpopular' [P1]; 'shifting priorities' [P2]; and the glimpsing of 'false summits' [P3]:

P2 I'm used to enterprise being a moving, a shifting priority at strategic level within the university. 
The literature identified how contextual influences (economic and political drivers in particular) had led to EU-wide HE policy reform and an increasing expectation of creating more 'Entrepreneurial Universities' (Mason 2014). All the HEIs in which the educators worked had 'bought in' at some level to the EE agenda (arguably evident by having these educators working in the EE area). However, it was perhaps surprising that, given their direct roles within EE, 5 out of the 10 educators have experienced negativity and/or 'blocking' to the EE agenda by senior management, illustrated by a range of examples from direct blocking of proposed changes [PP1], to a lack of understanding of what the EE entails [P3] and to insufficient funding to take the approved agenda forward [P8]. The data gathered evidenced general frustrations that the EE agenda tends to go 'in and out of fashion' and is particularly vulnerable to changing champions amongst senior managers which can impede long-term progress.

\section{Student-centred}

Many of the educators describe developing deep bonds with their students which some define as friendships/sibling like. This wasn't unexpected as educators are by their profession focussed on their students but what is perhaps surprising, is the depth of concern and relationships described, with many sharing their approach as being 'at one with their students' [P3] and of 'learning alongside them' [PP2]. Many are clearly frustrated (and some despair) [P3, P4 and P6], that such emotional engagement with learners is not considered 'normal' academic behaviour.

P3 That's the relationship that I tend to build up with the students [...] it's more of a sort of you know big brother type of guidance [...] but I feel very, very proud of them and that's something that I don't see necessarily with other academics.

Some may argue they act as existential educators. Merriam et al. (2007) explained that a key requirement of being an existential educator was a 'willingness to give of self' (2007, p. 156) through mutual relating. This was found with the majority of the educators researched.

P6 I am saying when I am talking to you all or 30 in the room, I am actually speaking to each one of you individually, so that you yourself explore as I do.

This high level of engagement with students' emotional and personal development appears to be an instinctive attribute of the educators studied, it is "who they are' and 'how they normally behave'.

P5 I knew them so well cos you know when you teach entrepreneurship subjects you tend to have different conversations with them. [...] you have eye contact with everybody, you know their names, you know when they're struggling. So, my personal...my being personal style suits that context. 


\section{Authenticity}

The philosophy of authenticity underpins many approaches to EE (Macht and Ball 2016) specifically within experiential learning. Authentic learning is said to help increase the self-efficacy of learners through their active engagement in an authentic 'industry-type' environment which facilitates the learners to become recognised members in the relevant community of practice (Lombardi 2007). Creating authentic learning experiences which would be of real value to learners was found to be important to the educators studied.

P1 I[...] have a local business [...] introduce a problem, I [...] get the students to respond to the [VLE] each week over a 4 week period, doing some work on that case study, coming up with some suggestions, contacting the business for more information and going on building the case that way.

Authenticity is highly personal, and the educators were very aware that it was important that the students, and not the educators, perceive the educational activities they engage with to be 'real' (Fook and Sidhu 2010, p. 159; Macht and Ball 2016, p. 930).

P1 it's like all adult education, it has to be purposeful and relevant and if entrepreneurship and this idea of being entrepreneurial and being involved in markets and being involved in trades, if that's not part of your identity or your professional identity then it becomes really meaningless.

\section{Effectuation}

The value of effectuation and of being an effectual educator with a strong sense of agency and creative purpose emerged as prominent in the educators researched (Fig. 1). They were keen to trial new ideas and actively harness a wide range of formal and informal resources and approaches to implement EE. There is an evidence research base (Sarasvathy 2001, 2009; Sarasvathy and Venkataraman 2011; Reymen et al. 2015) to illustrate the influence of effectual thinking within entrepreneurial behaviour. Amongst the majority of the educators, there was found to be evidence of such effectual approaches being adopted through, for example, active collaboration and networking to garner resources [PP2] and encouraging their students to do so, an emphasis on 'making things happen' [P2] with the resources available, and making it their business to 'know what's going on' [P2, $\mathrm{P} 4$ and P6].

P4 People say to me all of the time you know you're the perfect person to start a business why haven't you started a business and I say oh I do run a business it's my job [... I have a line manager but I own everything that I do, I create everything that I do, I find the money for things that I do, I negotiate with people all of the time. 
In summary, the data gathered indicate that all the educators appear to share deeply held values about the positive potential of EE for their students, which they consider needs to be implemented in a very student-centred way through their professional practice. All of the educators appear to align to social constructivist ideologies (Vygotsky 1929, 1978) and practices through creating entrepreneurially authentic learning environments (often using technology) and working and facilitating alongside their learners, with many developing deeper bonds, which some describe as friendship/sibling type. The educators express concerns about the need for socially responsible EE and many consider they have a personal responsibility to promote and facilitate this through their professional practice. There appears to be something more personal and multi-faceted about working in the field of EE that appeals to these educators than can be explained solely by an interest in business and entrepreneurship.

P6's comment below reveals his philosophy, which at some level the researcher became aware of in all the educators interviewed, though not always expressed with such passion.

P6 I want it to be transformational, I want them to get to the end of the programme and say holy god that was brilliant, I'm different, I feel different, I want to do more, I can't believe this was me.

\section{Identity}

The importance of personal and professional identity is a key finding of this research study, the educators recognising themselves primarily as entrepreneurial, unique, distinctive and non-traditional educators often identified as a friend or facilitator to their students (rather than the perceived more formal teacher/student) (Fig. 1).

\section{An entrepreneurial educator}

The results of the study found the majority of the educators' attitudes and behaviours reveal examples of entrepreneurial attributes, of: high levels of creativity orientation; opportunity awareness; comfort with risk and ambiguity; resilience and use of effectuation approaches. The majority (7 out of 10) of the educators prominently display a high level of creativity with a consequence that they have a propensity for new ideas, some may be disruptive [PP2, P4 and P6] and most have a 'need to' regularly change and find new challenges.

P8 I do see it quite a lot across the faculty where staff...they struggle cos they [...] just don't get it, that being more creative could actually enrich the development of [...] skills, attributes and [...] the capabilities of the students. 
Risk is an important theme for the majority of educators, whether in their own propensity to take and manage risk, and also to educate students in the language and reality of risk, often through the context of coping with ambiguity.

All the educators indicate a self-efficacy to drive action and the majority (8 out of 10 participants) prominently expose the characteristics of being able to deal with, and 'bounce-back' from, disappointment and failure (often illustrated through examples of poorly received or experimental EE experiences). A smaller number of the educators appear to constantly seek new challenges and tasks. These attributes appear to be very prominent within the described experiences and responses to experiences.

PP2 everybody said you can't do it, you can't set something up virtual in this space and, we didn't listen we just kept going.

All present as a highly entrepreneurial group of individuals, keen to nurture and utilise their personal experiences, resources and contacts through persuasion and collaboration in order to make things happen within their HEI, attitudes and behaviours which fits well with the concept of effectuation (Sarasvathy 2001) and bricolage (Baker and Melson 2005). It was found that this attitude prevails amongst the educators, with the majority going beyond their expected job role to 'make things happen', using their contacts and through the creative harnessing of resources.

P7 universities are terrible at making things work, so she [entrepreneur] still can't access our [...] So we had to find a way [...]

In 2011 Gibb reviewed how education could move from entrepreneurial concepts into educational practice and concluded that:

the practice and development of entrepreneurial behaviours is arguably there-

fore a core competence for entrepreneurship educators (Gibb 2011, p. 149).

This study has found this to be the case in practice, with these educators working the field of EE demonstrating many entrepreneurial behaviours.

\section{Entrepreneurship experience}

Shulman and Shulman (2004) developed an influential model of teacher development noting that teachers need to be able to integrate vision, motivation and understanding into their professional practice. There is an ongoing narrative in the media and in the education press that work experience should be a job pre-requisite (and part of ongoing professional learning) for all academics (Eder 2016; Chan 2018) to ensure that academics understand in practice, how to best prepare their students for the realities of industry and of our rapidly changing global economy. In the field of $\mathrm{EE}$, there has been an ongoing discussion as to whether an educator needs to have practical experience of entrepreneurship in order to have the necessary understanding of it to teach it (Pouspourika 2018). 
Each educator shared their career journey (before their current role) and the study found that the majority had very varied job histories (different types of roles) and (6 out of 10) had previous entrepreneurship experience (defined as founding or working in a small- or medium-sized business (SME)). Though there are limited available published data to compare this group with the general educator population, the results do suggest that educators working in the field of EE appear to have a high level of previous industry experience. The study found that having previous entrepreneurship experience was considered beneficial.

P8 that thing of anything's possible, that you [...] don't have to get a job, you can set [up] a business, you can go and do freelance work, you can do sort of portfolio work, it doesn't have to be a paid 9 to 5 job [...]. I think I probably try and [...] instil that in my students and I think cos I've done it, my colleagues who haven't done it think very, very different [...] it doesn't come across for them that there's anything but a paid employment.

It is important for policy makers and HEIs to consider how this can be fostered for academics in a university setting. Participant P6 acknowledges this issue in interviews and describes how he had established a mentor programme for academics to link with an SME to enhance their entrepreneurial experience. He considered it would not create the full experience but could help move the academics from theory to having a better understanding. Forming such connections at the outset of an academic career path was recommended in a review of business and university collaborations (BIS 2015) to enhance the environment for collaboration over the longer term.

However, for the three educators that did not have direct previous SME experience, it does not appear to be considered a disadvantage and two make use of practicing entrepreneurs as guest speakers and on live entrepreneurial challenges. One of the three educators with no prior entrepreneurship experience has since left university employ to start his own business (also indicating a level of comfort with entrepreneurship).

In conclusion, the majority of educators interviewed had had previous entrepreneurship experience (6 out of 10). Analysis of their stories and experiences indicates that all educators display moderate to high levels of personal entrepreneurial attributes, which are utilised within their professional practice. Though this research didn't set out with a hypothesis question: 'do I need to be entrepreneurial to teach entrepreneurship?' it found that identifying and behaving 'entrepreneurially' is important to the majority of the educators studied and this essence has been included as an important identity in the conceptual model (Fig. 1). The data indicated that it is not necessary to have prior entrepreneurship experience, though this appears useful for a deeper understanding of the realities and for some educators acts as enhanced credibility that they know what they are talking about through experience and not just theory. 


\section{Unique and distinctive}

Though not anticipated at the outset of this study, the research increasingly found the educators' sense of their own distinctive identity in that they 'think and act' differently to their peers within the university and this appears to be an important influencer of their experiences as educators in this field. Possibly also due to EE being an emerging discipline, many of the educators interviewed work alone or in small sections of HEIs also giving a level of distinctiveness within their university setting.

A literature search found the Need for Uniqueness Theory (NfU) (Snyder and Fromkin 1980) and Optimal Distinctiveness Theory (ODT) (Brewer 1991) which helped to better understand aspects of this experience. NfU recognises the human's need to feel special and distinctive. According to Snyder and Fromkin, individuals won't feel pleasant if they experience too much or too little similarity to others. A moderate level of uniqueness gives the optimal emotional response whereas, a very low or high level of similarity is suggested to lead to negative emotional reactions (Schumpe and Erb, 2015, p.1). The data gathered suggest the educators working in EE evidenced a high NfU, though most appeared comfortable with this most of the time.

PP1 I had a reputation of [doing] innovative things and to a certain extent that was because of who I was I was also not your typical [] teacher.

\section{P6 I don't conform}

Snyder and Fromkin (1980) found a positive relationship between individuals with a high NfU and high level of creative thinking, who were more likely to be willing to be non-conformist and tackle the status quo (Schumpe and Erb 2015), which many of the educators evidenced in their recounting of their experiences (for example, seeking changes to traditional assessment practices, project scopes, working with new disciplines, bringing in/working outside with new expertise).

P2 I'm an ideas person [...], I love ideas and new ideas but also I've always been quite interested in improvements and changes.

PP2 there is a pattern of being willing and able to do things that were not normal and accepted.

ODT (Brewer 1991) recognises that individuals have two fundamental but competing needs, a need to be distinctive and a need to 'belong' within social and other groups. According to ODT, these two identity drivers combine to produce a new characteristic, called 'the capacity for social identification' within distinctive groups. This study finds that the majority of the educators displayed a high need for distinctiveness whilst appearing to gain their belonging needs from the external $\mathrm{EE}$ academic community, rather than internally within their HEI [apart from two HEIs that were strategically 
committed to EE throughout the curriculum and where there appeared to be a more developed internal community of practice (Wenger 1998, 2000)].

The data also indicate downsides to being so 'distinctive': primarily emotional downsides experienced when students or staff don't want (or are suspicious of) the EE experience they have designed; when the trial and testing of a new initiative 'goes wrong' (though is often viewed as further evidence of acting entrepreneurially); loneliness experienced working mostly on their own in their HEI; the physical limit to what can be achieved on their own; and for some being viewed by management or colleagues as unreasonably focussed on enterprise.

P4 my hardest times are probably when I really think that something is so valuable, my students don't feel that it's as valuable, I then come back and reflect with some of my colleagues [...] kind of..."we don't care about enterprise like you do", that's what I find really hard.

The distinctive identity displayed by the majority of the educators studied was considered a significant theme and is presented within the conceptual model (Fig. 1).

\section{Pracademic}

In the interviews each educator touches on considerations of their professional development within their HEI and a view emerges that increasingly in HEIs, there are academics and there were 'pracademics' (practice-focussed academic), and it follows that most of the educators interviewed appear to feel most comfortable with the idea of a 'pracademic' identity.

P2 I really like sort of doing things, projects, making things happen, that's really more me.

P6 I'm not really a natural academic. I sort of use the term I'm a pracademic.

Some of the educators [P4 and P5] consider they 'had' to [or are expected to] 'do' more academic activity in order to comply with the expectations of their HEI and for P5 without this, there is a concern about a negative impact on future career progression. The data gathered indicate there is not a simple 'binary' position of academic versus the 'pracademic' but that there is a mixed picture with mixed identities, which many of the educators appear to manage well. There is found to be a perception that EE needs to be accepted more through traditional HEI academic forums in order to raise its value.

\section{Learning and teaching practices}

There is a great deal of consensus in the literature reviewed that EE requires a variety of 'active' experiential, cognitive and social learning approaches far beyond the transmission of knowledge content. The study finds the educators' 
professional learning and teaching practices to be very diverse, but there were common features amongst the majority: they have dynamic and responsive teaching repertoires; use in the main experiential and existential approaches; are willing to take risks to make things happen; practice alongside students; look for opportunities to assess process rather than outcomes; and demonstrate the need to support learning through growing social and community capital. A brief overview of these findings is discussed below and illustrated in the proposed conceptual model (Fig. 1).

The results found that many experiential and arguably existential approaches (requiring higher emotional and personal engagement) are being employed by the educators in the study to help develop entrepreneurial skills 'through' entrepreneurial experiences including: encouraging the experience of risk, ambiguity and learning through failure; creativity and idea generation; trading activities; business start-up type activities, and live business challenges and projects.

P1 We were looking for students to be challenged, we're looking for students to have problems so that they can solve the problems but we were also ensuring that the end result was a positive one.

Supporting their students to 'learn' from the experience of 'failure' is found to be very important though there are often challenges in convincing colleagues of the benefits.

P3 what we've found is that the reflections that have come back from the projects that have failed are considerably more in-depth and the notion of them being reflective than the ones that are succeeding.

Student start-up activities are viewed by many of the educators as the most 'entrepreneurial' of learning experiences, but many recognise that the majority of these remain very early stage. However, when activity becomes more 'real' many of the educators describe difficult situations where they have to help 'underwrite' various activities and secure necessary funding/permissions from other parts of the university.

P1 I did have to you know contact certain bodies in authority to request extra monies to underwrite certain things, which you know they look at you in, you do get that feeling of 'this isn't worth it.

Again, irrespective of how challenging a project or initiative proves to be in terms of their personal input, securing additional resources/approvals or where negative feedback is received, all the educators display a resilience and willingness to repeat and/or adapt such approaches as they firmly believe these approaches lead to valuable entrepreneurial competence development. 
P3 It frustrates the hell out of me because we're trying to encourage these students to be entrepreneurial but then there are barriers being put in our way to be able to actually provide that for them.

A significant finding of the study is that educators working in the field of EE are driven by a high degree of student centredness. This was regularly evidenced in how they described working with their students.

PP2 I said right, I'm taking strategy with you, one of the things about strategy is that it can either be prescriptive or emergent and we're off now. This is emergent. I've been asked to run a simulation with you. [...] You have to develop a strategy of understanding again and I'll have develop a strategy to support you, while you go through that.

How an individual educator personally copes with certain things such as ambiguity, is likely to affect how they integrate this within their practice (Palmer 1997). In the following comment, P1 considers this is an area of EE that many educators are not always comfortable.

P1 you have to be comfortable with a bit of uncertainty so if you're building an entrepreneurial environment then you build in uncertainty, you build in scope to make a mistake, you build in an element of risk and so we have colleagues that are very uncomfortable with that idea and dislike that.

The educators shared that not all students appeared to value the EE experiences at the time, though many cases were shared of them 'seeing the benefits' later.

P2 I have had students say to me that when they've made applications for jobs, graduate jobs. If they put their [EE project] that they did on their CV it's the one thing that employers really hone in on and want to talk to them about, they find it really interesting, employers I mean.

P4 I had a MSc [EE] module [...] and afterwards the student actually started up the business that they created through the module independently of the rest of his group [...] he said, "I joined the course [...] and I had no interest in enterprise and entrepreneurship as part of it at all. I was dreading the 40 credits that we would have on enterprise and entrepreneurship but actually those were the bits I took away the most.

Whilst it is de-motivating for educators when students don't immediately see the value in their experience in the main, any de-motivation appears to be a short-term phenomenon with the educators remaining ready to reflect, iterate and try again.

P7 it's okay to experiment, sometimes it goes right, sometimes it doesn't go right but its managing that experimentation. 
There was a great deal of consensus in the literature that EE needs appropriate and non-traditional types of assessment practices (as these experiences may or may not prove to have a successful outcome). Pittaway and Cope (2007) identified twelve key features required when aiming to stimulate entrepreneurial learning and one of those was to force students to step outside normal educational processes such as 'abandoning essays, exams and case studies for reflective accounts, reports and peer assessment' (2007, Table 2, p. 218). This study found the majority of educators had had to adjust (in some cases radically) existing assessment strategies in order to make their EE more effective, and for many this is described as a very challenging experience.

Many of the educators have had to reassure students, colleagues and quality assessment committees that new assessment regimes they are proposing will not place students at a disadvantage. For example, that process and reflection on the experience that process can be rigorously assessed, rather than purely assessing outcomes, as is typical of the exams (and other assessments) they are likely to have used/experienced in the past.

P3 the focus isn't on whether or not the project's a success, it's what they've actually learnt from the process, and we've had a lot of difficulties getting that through approval here.

Learning to develop social capital within EE has continued to gain momentum as social aspects are accepted as a key feature of entrepreneurial learning (Pittaway and Cope 2007, p. 223; Jones 2011; Pittaway et al. 2015). This research found many examples of educators creating social learning opportunities for their students through their personal teaching approaches, often by leveraging their own social capital.

P3 we're having a functional networking event in a hotel [...] inviting you know local businesses so that the students can actually network [...] you can tell somebody how to do it but unless they actually go out and try it themselves then they're not going to get really get the benefit from it.

As the interviews progressed, it became clear that a number of educators ( 7 out of 10) have felt isolated in their institution at times, and they emphasise the value they experience from linking with individuals and/or groups (or communities) of educators working in EE at other universities rather than just with colleagues within their own university (Wenger 1998, 2000). The findings suggest that this external relationship building was often facilitated through conferences and specialist EErelated professional learning programmes. However, one educator, P4 openly questioned the 'heathy' nature of the wider community 'group', 'why have we claimed enterprise', 'we carry on regardless', 'we should be checking in', reflecting calls in the literature for greater critically in the field (Fayolle 2013; Farny et al. 2016).

There are acknowledged challenges in the most effective methods of measuring the impact of EE, with many considering 'soft skill' developments being more likely than 
numbers of business start-ups. The difficulties in demonstrating the impact of EE are found to have wide implications at an institution and policy level.

P5 the measures I think are really difficult and I think that captures the dilemma of an enterprise educator cos how can we show what we have?

In the extract below, P6 details his experiences of trying to influence policy makers away from a simplistic target of business start-ups, arguing that we need to be looking for broader impact:

P6 I started to argue increasingly [...] to stop thinking about its all about starting businesses and start thinking about developing entrepreneurial thinking and entrepreneurial mind-set. The business starts will come after that, you are constantly starting too far down the process, you need to come back to the beginning.

\section{Professional learning}

EE-related professional learning was recognised as an influencing factor by 8 of the 10 educators, many consequently viewing themselves as more innovative and creative educators. The most recognised benefits were in relation to learning about new ideas or teaching tools and being reassured from the others on the programme (like-minded educators) that they were 'right thinking' and doing the 'right things' and in building community capital.

P5 I was just treading water and then I got introduced to this amazing group of people who knew every tool, every you know exciting thing and then that introduction changed, well it gave me a complete network of really clever people.

In summary, a wide variety of learning and teaching approaches are found to be used to develop students' entrepreneurial capacities including, networking, debates, case studies, digital simulation, role models, competitions, consultancy, interdisciplinary challenges and early business start-up. These take place generally in the safe environment of the university where students can learn and reflect on entrepreneurial skills valuable for the future, though examples were shared of external 'higher risk' activities. The main challenges experienced by educators were related to negotiating measurable targets, accessing necessary resources (such as gaining external input from entrepreneurs, industry specialists or sponsorship) and the open-ended time-intensive nature these activities can require. The value of the external community of educators working in $\mathrm{EE}$ as a support mechanism was found to be significant. 


\section{Conclusion}

Though contributions to theory or to macro-level findings were not primary objectives of this phenomenological study, the detailed data and insight gathered have led the researcher to: propose a simplified conceptual model of the phenomena of being an educator in EE, titled 'the Essence of Being an Entrepreneurial Educator'; contribute new insight regarding policy impact and institutional support for EE; and provide examples of educator approaches to interpreting and implementing EE.

Rideout and Gray (2013, p. 346) considered that EE appeared to be a phenomenon where actions and interventions had moved beyond the available theory and research evidence. The research aim was to gain an in-depth understanding of the experiences of UK-based HE educators working in this emerging field. Through employing IPA this study has achieved this aim by gaining a comprehensive understanding of the lived experiences of UK-based educators practicing in the field of EE and finds the reality to be complex, personal and emotionally charged.

Most of the educators are still working out what EE means for them within their practice (some after 10 years of practice), and there is a perception that EE is to an extent marginalised within many HEIs (or viewed suspiciously), and perceived as having a lower academic status than many other disciplines. These 'downsides' create challenges in terms of securing wider buy-in and for some they perceive a negative impact on career development (though there is limited evidence to support this). However, other educators felt the 'notoriety' of such distinctiveness within their HEI provides greater opportunities.

There are clear frustrations that though there are a plethora of EE-related policy and 'good intentions', within many institutions the EE agenda tends to go 'in and out of fashion' and is vulnerable to changing champions amongst senior managers. A lack of institutional support can significantly restrict activity which some of the educators will seek to find a way around. COVID-19 is already found to be increasing calls for more/enhanced EE and care needs to be taken to ensure such change is collaborative, supported across disciplines and integrates with wider institutional developments and is not viewed as a 'fashionable' quick fix.

The wider community of educators working in this field is found to be a vital source of renewal and inspiration for many of the educators. The educators evidence high levels of agency and are driven by a strong belief in the 'goodness' and values of EE and of the benefits for students in learning to be more entrepreneurial, whether students intend to set up a business or more typically to enhance their employability opportunities in the future through learning the higher-order skills associated with being enterprising. There are acknowledged challenges in the most effective methods of measuring the impact of EE, with many considering 'soft skill' developments being more likely than the creation of business startups, whilst recognising the difficulties in capturing this.

Most of the educators have encountered lack of interest and rejection from both colleagues and students in performing their role, but all display the resilience to come back from disappointment and view these occasions as opportunities to 
learn in order to find new ways to develop more effective solutions. The repertoire of EE is constantly evolving with many of the educators acting as 'champions' with their colleagues. The educators appear to consider that they themselves need to act as entrepreneurial role models (through, for example, coping with, and learning from, failure) for their students and colleagues.

In terms of identity, being an educator working in this field appears to attract entrepreneurial and creative individuals with a high need for uniqueness and actionorientation, who are comfortable in being considered distinctive and willing to challenge (and to encourage others to challenge) accepted traditional practices in all areas of the educational environment. Overall, it is concluded that there seems to be something distinct and more personal about working within the field of EE which attracts particular educators. All the educators had consciously 'chosen' to work in this field and their participation seems to be profoundly based on their own personal philosophy of learning, rather than a sole concern with enterprise or new business and on the 'promise' of a better future for their learners which they consider EE can offer.

There is a consensus that more research is required to better understand what works in EE, for whom and the longer-term impacts this has on students, organisations and society. This study has proposed an initial conceptual framework of the essence of EE from an educators' perspective as a starting point for further exploration. It has shared much-needed perspectives on the realities of the enactment of EE policy and of how change can happen within our education system and will be of interest to education and economic policy makers, university senior management and organisational development managers.

\section{The time to reimagine but also to act}

A recent, but pre-COVID-19, report issued by the European Commission highlights many key benefits which entrepreneurship brings to corporate and public organisations (rather than a traditional focus on SMEs), for example, to 'help future-proof the organisation's strategy and purpose" and "challenge the organisation's world view' (Lackéus, Lundqvist, Williams Middleton, Inden, 2020, p.20), for this to happen it says organisations need entrepreneurial employees. Entrepreneurial employees are defined here as:

someone who cares so much about an issue that she takes collaborative action despite inherent uncertainty and risk, trying to create something new envisioned to be of significant value for others, and who does this in a process characterised by trial-and-error based learning. She tries hard to envision, experiment and collaborate in order to create new kinds of value for other people (Lackéus et al. 2020, p. 9).

This study has found the educators working in this field meet this new definition in full. They are entrepreneurial educators but also entrepreneurial employees working within the university system. 
The urgent and widely accepted need for our education systems to be reviewed, reimagined (Peters et al. 2020; RSE 2020) or 'reset' (WEF 2020) post-COVID-19 includes calls for reviews of structures, delivery models, programme content, research and innovation. This group of educators - as entrepreneurial employeescan help to broaden and strengthen this process (beyond the confines of existing university structures) by working collaboratively, and they can help colleagues embrace uncertainty, reimagine programmes and support transformative action to reinvigorate and enhance education systems post-COVID-19.

\section{Compliance with ethical standards}

Conflict of interest The author states there is no conflict of interest.

\section{References}

Acs, K. J., \& Virgill, N., (2010). Chapter 18: Entrepreneurship in developing countries. In: Acs, Z. K., \& Audretsch, D. B. (eds.) 2nd Edition of the Handbook of Entrepreneurship Research. Springer

Baker, T., \& Nelson, R. E. (2005). Creating something from nothing: Resource construction through entrepreneurial bricolage. Administrative Science Quarterly, 50(3), 329-366.

Bandura, A. (1977). Social learning theory. New York: General Learning Press.

Bhatia, B. K., \& Levina, L. (2020). Can entrepreneurship be taught in a classroom? Harvard business review. Available: https://hbr.org/2020/08/can-entrepreneurship-be-taught-in-a-class room?ab=hero-main-text.

BIS (2015). The Dowling Review of Business-University Research Collaborations. Available https:// www.gov.uk/government/uploads/system/uploads/attachment_data/file/440927/bis_15_352_The_ dowling_review_of_business-university_rearch_collaborations_2.pdf.

BIS. (Young, Lord) (2014). Enterprise for all: The relevance of enterprise in education, Department of Business Innovation and Skills. Available: https://www.gov.uk/government/publications/enterprise -for-all-the-relevance-of-enterprise-in-education.

Brewer, M. B. (1991). The social self: On being the same and different at the same time. Personality and Social Psychology Bulletin, 17(5), 475-482.

BROWN, T., (2008). Design Thinking. Harvard Business Review, pp. 85 - 92.

Cacciotti, G., Hayton, J. C., Mitchell, R., \& Giazitzoglu, A. (2016). A reconceptualization of fear of failure in entrepreneurship. Journal of Business Venturing, 31, 302-325.

Caird, S., \& Johnson, C. (1988). The general measure of enterprising tendency (GET) test. Durham University Business School. Available: http://www.get2test.net/.

Carlson, A., (2002). Authentic learning: What does it really mean? Western Washington University. Retrieved from: http://pandora.cii.wwu.edu/showcase2001/authentic_learning.htm.

Chan, C. (2018). Work experience should be a job requirement for academics. Times Higher Education. Available: https://www.timeshighereducation.com/opinion/work-experience-should-be-job-requi rement-academics.

Chapman, E., \& Smith, J. A. (2002). Interpretative phenomenological analysis and the new genetics. Journal of Health Psychology, 7(2), 125-130.

Clandinin, D. J., \& Connelly, F. M. (2000). Narrative inquiry: Experience and story in qualitative research. Jossey-Bass Inc.

Craft, A. (2011). Creativity and education futures: Learning in a digital age. Stoke-on-Trent: Trentham Books.

Krueger, N. F. Jr., \& Day, M. (2010). Looking forward, looking backward: From entrepreneurial cognition to neuroentrepreneurship. Chapter 13, In: Acs, Z. K., \& Audretsch, D. B. (eds.) 2nd Edition of the Handbook of Entrepreneurship Research. Springer. pp. 321-358.

Desa, G., \& Basu, S. (2013). Optimization or bricolage? Overcoming resource constraints in global social entrepreneurship. Strategic Entrepreneurship Journal, 7(1), 26-49. 
Dewey, J. (1938). Experience and education, the kappa delta pi lecture Series. New York: Macmillan.

Duening, T. N. (2010). Five minds for the entrepreneurial future: Cognitive skills as the intellectual foundation for next generation entrepreneurship curricula. The Journal of Entrepreneurship, 19(1), $1-22$.

Dunham, L., Venkataraman, S., (2006). From rational to creative action: Recasting our theories of entrepreneurship. Darden Graduate School of Business Administration, University of Virginia, Working Paper 02-06.

Dweck, C. S. (2007). Mindset: The new psychology of Success. Ballantine Books.

Eder, W. E. (2016). More academic staff need industry experience. ASEE Prism, 26(1), 10.

European Commission (EC), (2006). The oslo agenda for entrepreneurship education in Europe http:// ec.europa.eu/enterprise/policies/sme/files/support_measures/training_education/doc/oslo_agend a_final_en.pdf.

European Commission (EC). (2007). Key competencies for lifelong learning: European reference framework. Available https://ec.europa.eu/education/policy/school/competences_en.

European Commission (EC) (2008). Entrepreneurship in higher education, especially within non-business studies. Final report of the Expert Group. Available https://ec.europa.eu/growth/content/final -report-expert-group-entrepreneurship-higher-education-especially-within-non-business-0_en.

European Commission (EC), (2009). Entrepreneurship in vocational education and training: Final report of the expert group. Available https://www.abdn.ac.uk/spe/documents/Entrepreneurship_educa tion_European_Comission/Entrepreneurship_in_vocational_education_and_training.pdf.

European Commission (EC), (2011a). Entrepreneurship education: enabling teachers as a critical success factor 'a report on teacher education and training to prepare teachers for the challenge of entrepreneurship education'. Available http://ec.europa.eu/enterprise/policies/sme/promoting-entre preneurship/files/education/teacher_education_for_entrepreneurship_final_report_en.pdf.

European Commission (EC), (2011b). Order 129: Mapping of teachers' preparation for entrepreneurship education-No EAC 19/06. Available http://edz.bib.uni-mannheim.de/daten/edz-b/gdbk/11/mappi ng_en.pdf.

European Commission (EC), (2013). Entrepreneurship education: Enterprise and industry a guide for educators. Available http://ec.europa.eu/enterprise/policies/sme/promoting-entrepreneurship/files/ education/entredu-manual-fv_en.pdf.

European Commission (EC), (2014a). Exploring the potential social and economic impact of entrepreneurship in education (2014:8), Thematic Working Group on Entrepreneurship Education, Final Report November 2014. Available http://ec.europa.eu/education/policy/strategic-framework/archi ve/documents/entrepreneurship-report-2014_en.pdf.

European Commission (EC), (2014b). HEInnovate. Available https://heinnovate.eu/intranet/tef_guide/ about.php.

European Commission (EC), (2015a). Entrepreneurship education: A road to success: A compilation of evidence on the impact of entrepreneurship education strategies and measures, Luxembourg: Publications Office of the European Union. ISBN 978-92-79-44556-9. Available http://ec.europa.eu/ growth/tools-databases/newsroom/cf/itemdetail.cfm?item_id=8056\&lang=en.

European Commission (EC), (2015b). Promoting entrepreneurship. Available http://ec.europa.eu/growth/ smes/promoting-entrepreneurship/support/education/index_en.htm.

European Commission (EC), (2016). EntreComp: The entrepreneurship competence framework. Available https://ec.europa.eu/jrc/en/entrecomp.

Farny, S., Frederiksen, S. H., Hannibal, M., \& Jones, S. (2016). A CULTure of entrepreneurship education. Entrepreneurship \& Regional Development, 28(7-8), 514-535.

Fayolle, A. (2013). Personal views on the future of entrepreneurship education. Entrepreneurship \& Regional Development, 25(7-8), 692-701.

Finlay, L. (2012). Chapter 2. Debating phenomological methods. In Friesen, N. et al (eds) Hermeneutic phenomenology in education. Sense Publishers.

Fook, C. Y., \& Sidhu, G. K. (2010). Authentic assessment and pedagogical strategies in higher education. Journal of Social Sciences, 6(2), 153-161.

Garrison, J., Neubert, S., Reich, K. (2012). John dewey's philosophy of education. Palgrave Macmillan. Available http://www.palgraveconnect.com/pc/doifinder/10.1057/9781137026187.

Gibb, A. A. (2002). In pursuit of a new 'enterprise' and 'entrepreneurship' paradigm for learning: Creative destruction, new values, new ways of doing things and new combinations of knowledge. International Journal of Management Reviews, 4(3), 233-269. 
Gibb, A. A. (2009). Towards the entrepreneurial university. entrepreneurship education as a lever for change, National Council for Graduate Entrepreneurship (NCGE) UK. Available http://ncee.pw/ wp-content/uploads/2013/12/towards_the_entrepreneurial_university.pdf.

Gibb, A. A. (2011). Concepts into practice: Meeting the challenge of development of entrepreneurship educators around an innovative paradigm: The case of the International Entrepreneurship Educators' Programme (IEEP). International Journal of Entrepreneurial Behaviour \& Research, 17(2), $146-165$.

Green, J., \& Thorogood, N. (2014). Qualitative methods for health research. SAGE, Third edition.

Hagg, G., \& Kurczewska, A. (2016). Connecting the dots: A discussion on key concepts in contemporary entrepreneurship education. Education Training, 58(7), 700-714.

Hart, P., (2008). What comes before participation? searching for meaning in teachers' constructions of participatory learning in environmental education. In Reid, A., Jensen, B. B., Nikel, J., \& Simovska, V., (eds.) Participation and learning: Perspectives on education and the environment, health and sustainability (pp. 197-211). New York: Springer.

Heidegger, M., (1927). (Reprinted 1962) Being and time, Trans. by John Macquarrie and Edward Robinson. New York: Harper \& Row. From the German original of 1927. Cited in: Smith, D Woodruff (2013) Phenomenology. The Stanford Encyclopaedia of Philosophy. Winter 2013 Edition. Edward N. Zalta (ed.).

Heinonen, J., \& Hytti, U. (2010). Back to basics: the role of teaching in developing the entrepreneurial university. The International Journal of Entrepreneurship and Innovation, 11(4), 283-292.

Henry, C. (2013). Entrepreneurship education in HE: Are policy makers expecting too much? Education and Training, 55(8/9), 836-848.

Henry, C., \& Lewis, K. (2018). A review of entrepreneurship education research: Exploring the contribution of the education + training special issues. Education + Training, 60(3), 263-286.

Holcomb, T. R., Ireland, R. D., Holmes Jr. R. M., \& Hitt, M. A. (2009). Architecture of entrepreneurial learning: Exploring the link among heuristics, knowledge, and action. Baylor University.

Hwang, S. (2008). Teachers' stories of environmental education: blurred boundaries of professionalism, identity and curriculum. Thesis submitted for Doctor of Philosophy, University of Bath.

Jarvis, P., (2006). Towards a comprehensive theory of human learning. London: Routledge. Cited in: Charteris, J., Quinn, F., Parkes, M., Fletcher, P., \& Reyes, V., (2016). e-Assessment for learning and performativity in higher education: A case for existential learning. Australasian Journal of Educational Technology, 32(3): 112-122.

Jones, C., (2011). Teaching Entrepreneurship to Undergraduates. Edward Elgar Publishing Limited.

Jones, C., Matlay, H., Penaluna, K., \& Penaluna, A., (2014). Claiming the future of enterprise education. Education + Training, 56(819): 764-775.

Kauffman (2015). Kauffman thoughtbook 2015. Available http://www.kauffman.org/thoughtbook2015/ starting-our-course\#wordsweliveby.

Kember, D. (2009). Promoting student-centred forms of learning across an entire university. Higher Education, 58(1), 1-13.

Kolb, D. A. (1984). Experiential learning. Englewood Cliffs: Prentice Hall.

Kyrö, P. (2015). The conceptual contribution of education to research on entrepreneurship education. Entrepreneurship \& Regional Development, 27(9-10), 599-618.

Lackeus, M (2019) Chapter 12: Making enterprise education more relevant through mission creep Mulholland, G., \& Turner, J., (eds). Enterprising education in UK higher education: Challenges for theory and practice. Routledge Studies in Entrepreneurship, pp. 273-295.

Lackeus, M., Lundqvist, M., Williams Middleton, K., Inden, J. (2020). The entrepreneurial employee in the public and private sector-what, why, how (M. Bacigalupo Ed.), EUR 30108 EN, Publications Office of the European Union, Luxembourg, 2020, ISBN 978-92-76-16651-1, https://doi. org/10.2760/460123, JRC117661.

Lackéus, M., (for OECD) (2015). Entrepreneurship in education, what why when and how, entrepreneurship 360 background paper. Available http://www.oecd.org/cfe/leed/BGP_Entrepreneurship-inEducation.pdf.

Langston, C (2018) An interpretative phenomenological analysis of educators' experiences of entrepreneurship education in UK HEIs, University of Aberdeen, ISNI: 0000000474320437.

Levi-Strauss, C., (1967). The savage mind. University of Chicago Press: Chicago, IL. Cited In: Baker, T., \& Nelson, R. E., (2005). Creating something from nothing: Resource construction through entrepreneurial bricolage. Administrative Science Quarterly, 50(3): 329-366. 
Lepistö, J. and Ronkko, M-L., (2013). Teacher students as future entrepreneurship educators and learning facilitators. Education + Training, 55(7): 641-653.

Lewin, K., (1946/1948). Action research and minority problems (In G.W. Lewin (Ed.), Resolving social conflicts (pp. 201-216). New York: Harper \& Row). Cited in D. Bargal (2008) Action research: A paradigm for achieving social change. Small Group Research, 39(1): 17-27.

Lombardi, M. M., (2007). Authentic learning for the 21st century: An overview, EDUCAUSE. ELI Paper 1. Retrieved August 24, 2015 from http://academic.research.microsoft.com/Paper/5468402.aspx.

Lucas, W. A., \& Cooper, S. Y. (2004). Enhancing self-efficacy to enable entrepreneurship: The case of CMI's connections. MIT Sloan Working Paper, No. 4489-04.

Macht, S. A., \& Ball, S. (2016). Authentic alignment-a new framework of entrepreneurship education. Education + Training, 58(9), 926-944.

Maguire, R., Egan, A., Hyland, P., \& Maguire, P. (2017). Engaging students emotionally: The role of emotional intelligence in predicting cognitive and affective engagement in higher education. Higher Education Research \& Development, 36(2), 343-357.

Mason, C., (for quality assurance agency (Scotland)), (2014). Creating Entrepreneurial Campuses. Available http://www.enhancementthemes.ac.uk/flexible-learning/enterprise-and-entrepreneurship.

McClelland, D. C. (1965). Need achievement and entrepreneurship: A longitudinal study. Journal of Personality and Social Psychology, 1, 389-392.

Merriam, S. B., Caffarella, R. S., \& Baumgartner, L. M. (2007). Learning in adulthood. San Francisco: Jossey-Bass. In Walters, D. A., (2008). Existential being as transformative learning. Pastoral Care in Education, 26(2): 111-118.

Miner, J. B. (1990). Entrepreneurs, high growth entrepreneurs, and managers: Contrasting and overlapping motivational patterns. Journal of Business Venturing, 5(4), Abstract.

Moltz, B. J. (2008). Bounce! failure resiliency and confidence to achieve your next great success. Hoboken: Wiley.

Moustakas, C. (1994). Phenomenological Research Methods. London: Sage Publications.

Palmer, P. J. (1997). The courage to teach: exploring the inner landscape of a teacher's life. Jossey-Bass Inc.

Patton, M. Q., (1990). Qualitative evaluation and research methods. 2nd edition. Newbury Park, CA: Sage. Cited in: Green, J., \& Thorogood, N., (2014). Qualitative methods for health research. SAGE, Third edition, p. 122.

Penaluna, A., \& Penaluna, K. (2009). Assessing creativity: Drawing from the experience of the UK's creative design educators. Education + Training, 51(8), 718-732.

Peters, M. A., Rizvi, F., McCulloch, G., Gibbs, P., Gorur, R., Hong, M., Hwang, Y., Zipin, L., Brennan, M., Robertson, S., Quay, J., Malbon, J., Taglietti, D., Barnett, R., Chengbing, W., McLaren, P., Apple, R., Papastephanou, M., Burbules, N., Jackson, L., Jalote, P., Kalantzis, M., Cope, B., Fataar, A., Conroy, J., Misiaszek, G., Biesta, G., Jandric, P., Choo, S. S., Apple, M., Stone, L., Tierney, R., Tesar, M., Besley, T., Misiaszek, L. (2020): Reimagining the new pedagogical possibilities for universities post-COVID-19, Educational Philosophy and Theory, https://doi.org/10.1080/00131 857.2020.1777655. Available https://www.tandfonline.com/doi/pdf.

Piaget, J. (1972). Psychology and epistemology, P. A.Wells, trans. (Harmondsworth, Penguin). Cited in: Bateson, T. E. P. (2012). Constructivist pedagogy and symbolism: Vico, Cassirer, Piaget. Educational Philosophy and Theory, 44(8): 878-891.

Pittaway, L., \& Cope, J. (2007). Simulating entrepreneurial learning integrating experiential and collaborative approaches to learning. Management Learning, 38(2), 211-233.

Pittaway, L., \& Edwards, C. (2012). Assessment: Examining practice in entrepreneurship education. Education + Training, 54(8), 778-800.

Pittaway, L. A., Gazzard, J., Shore, A., \& Williamson, T. (2015). Student clubs: Experiences in entrepreneurial learning. Entrepreneurship \& Regional Development, 27(3-4), 127-153.

POUSPOURIKA, L (2018) Can entrepreneurship be taught? Institute of Entrepreneurship Development. Available: https://ied.eu/project-updates/can-entrepreneurship-be-taught/

Powietrzynska, M., Tobin, K., \& Alexakos, K. (2015). Facing the grand challenges through heuristics and mindfulness. Cultural Studies of Science Education, 10(1), 65-81.

Prodon, I., \& Drnovsek, M. (2010). Conceptualizing academic-entrepreneurial intentions: An empirical test. Technovation, 30(5), 332-347.

Quality Assurance Agency. (2012). Enterprise and entrepreneurship education: Guidance for UK higher education providers. Available http://supporthere.org/sites/default/files/uk_qaa-entrepreneurshi p-guidance_2012.pdf. 
Quality Assurance Agency. (2018). Enterprise and entrepreneurship education: Guidance for UK higher education providers. https://www.qaa.ac.uk/docs/qaas/enhancement-and-development/enterprise -and-entrpreneurship-education-2018.pdf?sfvrsn=15f1f981_8.

Quality Assurance Agency Scotland, (2014). Creating Entrepreneurial Campuses. Available http://www. enhancementthemes.ac.uk/docs/report/creating-entrepreneurial-campuses.pdf?sfvrsn=14.

Rae, D. (2010). Universities and enterprise education: Responding to the challenges of the new era. Journal of Small Business and Enterprise Development, 17(4), 591-606.

Ratten, V., (2020) Coronavirus (COVID-19) and the entrepreneurship education community. Journal of Enterprising Communities: People and Places in the Global Economy, Vol. ahead-of-print No. ahead-of-print. https://doi.org/10.1108/JEC-06-2020-0121. Available https://www.emerald.com/ insight/content/doi/10.1108/JEC-06-2020-0121/full/html.

Reymen, I., Berends, A. P., Mauer, H., Stephan, R., \& Van Burg, E. U. (2015). Understanding dynamics of strategic decision making in venture creation: a process study of effectuation and causation. Strategic Entrepreneurship Journal, 9(4), 351-379.

Rideout, E. C., \& Gray, D. O. (2013). Does entrepreneurship education really work? A review and methodological critique of the empirical literature on the effects of university-based entrepreneurship education. Journal of Small Business Management, 51(3), 329-351.

Robinson, S., Neergaard, H., Tanggaard, L., \& Krueger, N. (2016). New horizons in entrepreneurship education: From teacher-led to student-centred learning. Education Training, 58(7), 661-683.

RSE (2020) SFC review of the coherence and sustainability of tertiary education provision: RSE fellows and young academy discussion summary. RSE Advice Paper No: 20-15. Available https://www.rse. org.uk/wp-content/uploads/2020/08/SFC-review-discussion.pdf.

Sadala, M. L. A., \& Adorno, R. C. F. (2002). Phenomenology as a method to investigate the experience lived: A perspective from Husserl and Merleau Ponty's thought. Journal of Advanced Nursing, 37(3), 282-293.

Sarasvathy, S. D. (2001). Causation and effectuation: Toward a theoretical shift from economic inevitability to entrepreneurial contingency. The Academy of Management Review, 26(2), 243-263.

Sarasvathy, S. D. (2009). Effectuation: Elements of entrepreneurial expertise. Cheltenham: Edward Elgar Publishing.

Sarasvathy, S. D., \& Venkataraman, S. (2011). Entrepreneurship as method: Open questions for an entrepreneurial future. Entrepreneurship Theory and Practice, 35(1), 113-135.

Schleiermacher, F. (1998). Hermeneutics and criticism and other writings (A.Bowie, Trans). Cited in: Flowers, J. A., \& Larkin, M. (2009). Interpretative Phenomenological Analysis: Theory, Method and Research, Sage.

Schumpe, B. M., \& Erb, H. P. (2015). Humans and uniqueness. Science Progress, 98(1), 1-11.

Shapero, A. (1975). The displaced, uncomfortable entrepreneur. Psychology Today, 8, 83-88.

Shulman, L. S., \& Shulman, J. H. (2004). How and what teachers learn: A shifting perspective. Journal of Curriculum Studies, 36(2), 257-271.

Smith, D. W. (2013). Phenomenology. The Stanford Encyclopaedia of Philosophy, Winter 2013. Available http://plato.stanford.edu/archives/win2013/entries/phenomenology/.

Smith, J. A., Flowers, P., \& Larkin, M. (2009). Interpretative phenomenological analysis: Theory, method and research. Thousand Oaks: Sage.

Snyder, C. R., \& Fromkin, H. L. (1980). Uniqueness: The human pursuit of difference. Plenum Press, New York. In: Schumpe, B. M., \& Erb, H-P (2015) Humans and uniqueness. Science Progress, 98(1): $1-11$.

Stewart, W. H., \& Roth, P. L. (2007). A meta-analysis of achievement motivation differences between entrepreneurs and managers. Journal of Small Business Management, 45, 401-421.

Tanggaard, L. (2014). A situated model of creative learning. European Educational Research Journal, $13(1), 107-116$.

Vanhear, J. (2013). The use of concept mapping and vee heuristics in higher education to promote critical reflection and meaningful learning. Journal for Educators, Teachers and Trainers JETT, 4(1), 80-194.

Vygotsky, L. S. (1929). The problem of the cultural development of the child. Pedagogical Seminary and Journal of Genetic Psychology, 36(3), 415-434.

Vygotsky, L. S. (1978). Mind and society: The development of higher psychological processes. Cambridge: Harvard University Press.

Walters, D. A. (2008). Existential being as transformative learning. Pastoral Care in Education, 26(2), $111-118$. 
Ward, T. B. (2004). Cognition, creativity, and entrepreneurship. Journal of Business Venturing, 19(2), 173-188.

Welter, C., Mauer, R. and Wuebker, R. J. (2016). Bridging behavioral models and the theoretical concepts: Effectuation and bricolage in the opportunity creation framework. Strategic Entrepreneurship Journal, 10, 5-20.

Welpe, I. M., Sporrle, M., Grichnik, D., Michl, T., \& Audretsch, D. B. (2012). Emotions and opportunities: the interplay of opportunity evaluation, fear, joy, and anger as antecedent of entrepreneurial exploitation. Entrepreneurship: Theory and Practice, 36(1), 69-96.

Wenger, E. (1998). Communities of practice: Learning, meaning and identity. Cambridge: Cambridge University Press.

Wenger, E. (2000). Communities of practice and social learning systems. Organization, 7(2), 225-246.

World Bank (Authored by, Alexandria Valerio, Brent Parton, and Alicia Robb) (2014). Entrepreneurship education and training programs around the world: dimensions for success. Available https:// openknowledge.worldbank.org/handle/10986/18031.

World Economic Forum (WEF), (2011). Educating the next wave of entrepreneurs: Unlocking entrepreneurial capabilities to meet the global challenges of the 21st Century. Available http://www.wefor um.org/reports/educating-next-wave-entrepreneurs.

World Economic Forum (WEF) (2020) Great reset: What university entrepreneurship can bring to the post-COVID world. Available https://www.weforum.org/agenda/2020/07/university-entreprene urship-post-COVID-19-world/.

World Health Organisation (2020) Coronavirus disease (COVID-19) pandemic, https://www.who.int/ emergencies/diseases/novel-coronavirus-2019.

Zahra, S. A., Gedajlovic, E., Neubaum, D. O., \& Shulman, J. M. (2009). A typology of social entrepreneurs: Motives, search processes and ethical challenges. Journal of Business Venturing, 24, $519-532$.

Publisher's Note Springer Nature remains neutral with regard to jurisdictional claims in published maps and institutional affiliations. 